\title{
LEED Study of Green Lightweight Aggregates in Construction
}

\author{
Fahad K. Alqahtani ${ }^{1, *(\mathbb{D} \text {, Ibrahim S. Abotaleb }}{ }^{2}$ and Sara Harb ${ }^{2}$ \\ 1 Department of Civil Engineering, College of Engineering, King Saud University, P.O. Box 800, \\ Riyadh 11421, Saudi Arabia \\ 2 Department of Construction Engineering, School of Sciences and Engineering, The American University in \\ Cairo, P.O. Box 74, New Cairo 11835, Egypt; ibrahimsalah@aucegypt.edu (I.S.A.); \\ saraharb@aucegypt.edu (S.H.) \\ * Correspondence: bfahad@ksu.edu.sa
}

check for updates

Citation: Alqahtani, F.K.; Abotaleb, I.S.; Harb, S. LEED Study of Green Lightweight Aggregates in Construction. Sustainability 2021, 13, 1395. https://doi.org/10.3390/ su13031395

Received: 27 December 2020

Accepted: 26 January 2021

Published: 29 January 2021

Publisher's Note: MDPI stays neutral with regard to jurisdictional claims in published maps and institutional affiliations.

Copyright: (C) 2021 by the authors. Licensee MDPI, Basel, Switzerland. This article is an open access article distributed under the terms and conditions of the Creative Commons Attribution (CC BY) license (https:/ / creativecommons.org/licenses/by/ $4.0 /)$.

\begin{abstract}
Decreasing the demand for natural aggregates is doubly justified by the significant contribution of the construction industry to the unsustainable development path of the natural environment, and the projected global increase of the consumption of construction aggregates. Extensive research has been carried out on the physical and mechanical properties of concrete which incorporates plastic as aggregates; yet, no single study has been able to draw on structured research which demonstrates the improved sustainability performance of plastic-based aggregates to support sustainable development in the construction industry for a project seeking Leadership in Energy and Environmental Design (LEED) certification. The goal of this research is to explore the potential benefits that green processed lightweight aggregates (PLA) can provide to a project seeking LEED certification in accordance with the requirements of LEED v4 for Building Design and Construction. The objectives are to: (1) determine which LEED credit requirements can be met through using the studied material; (2) provide a comprehensive analysis of the applicable attainable LEED credits, given the existing technical information of the selected material, and (3) provide guidelines to maximize further credit attainment. To this end, the findings indicated that the use of PLA as a total replacement for coarse aggregates in lightweight concrete applications would contribute to earning directly up to 8 points (out of 110 total points) towards LEED certification. Such significant number allows for the potential increase of the project's certification by one level. This is the first study of its kind to investigate the improved sustainability performance of recycled plastic aggregates from a LEED point of view. Moreover, the guidelines provided by the research will enable developers to maximize the financial and environmental benefits of their buildings through the reduced lifecycle cost and the enhanced LEED score. This research should encourage project teams to incorporate the knowledge of sustainable practices, and play an active role in sustainable development.
\end{abstract}

Keywords: LEED; PLA; plastic; sustainable development; financial and environmental benefits

\section{Introduction}

The rapid increase in urbanization in developing countries is ultimately coupled with an unprecedented growth rate of the global building sector [1,2] With this, the world is expected to reach an alarming approximate area of 230 billion square meters of new construction over the next 40 years [1]. Global environmental awareness has gained momentum over the last few decades, due to the increasing emergence of a wide range of environmental concerns, such as climate change, deforestation, pollution, energy security, water stress and pollution, and shortage of natural resources [3]. The application of sustainability principles within the construction industry has been advocated by researchers within the past decades [4], which has become of exceeding relevance at the present time due to the increase in global cement production, and related carbon dioxide emissions, in addition to the rising demand for natural resources, such as water, aggregate, limestone, and energy [3]. Moreover, the industry is responsible for a significant volume 
of construction-related waste and emissions, which accounts for 13-30\% of global waste generation [5], and 39\% of energy-related carbon dioxide emissions [1].

Concrete is one of the most common building materials used in the construction and infrastructure industries [6] with a global annual production of 20 billion tons in 2015 [7]. Aggregates typically occupy $55-80 \%$ of the volume of concrete [8]. A growing body of literature has examined the use of secondary materials as an alternative source of aggregates in construction applications [9-12]. The validity of the argument is further emphasized by the projected global increase of $2.3 \%$ per year of the consumption of construction aggregates to reach 47.5 billion metric tons by 2023 [13].

Reducing the demand for natural aggregates for concrete applications is doubly justified based on the economic and environmental benefits such as reducing the overexploitation of aggregate quarries, consequent energy consumption, and associated greenhouse gas (GHG) emissions [14-19]. To mention details of a few aspects, mining quarries and solid waste landfill sites have a significant negative impact on groundwater systems [20]. Similarly, the extraction of fine aggregates from shorelines has an adverse impact on native flora and fauna ecosystems [21]. The study of Udom [21] revealed that the extraction of aggregates from floodplains resulted in a significant amount of increasing land loss from $47.14 \%$ to $112.9 \%$, within the years 2013 to 2017 respectively. Additionally, the use of natural aggregates accounts for $13 \%$ to $20 \%$ of the total $\mathrm{CO}_{2}$ emissions from concrete production [19].

The projected global demand for construction aggregates will exacerbate the existing social, economic, and environmental threats associated with the production and use of natural aggregates, which created the need for researchers to introduce sustainable materials as a replacement for coarse and fine aggregates in the industry. Various studies have been published on the use of alternative waste materials to natural aggregates in concrete production, like egg shell powder [22], waste ceramic tiles [23], coconut shells, crushed waste glass [24], brick waste [25], waste paper ash pellets [26], and several others.

Alqahtani et al. [27] introduced and patented a new type of synthetic light-weight aggregate. The binder material is based on recycled plastic made from linear low-density polyethylene (LLDPE) obtainable in three different forms: shredded, granulated, and powdered. After collection from a local supplier, all three types of plastic are purified, shredded, melted, pelletized, and are finally fabricated into a powdered form. The different types of filler materials used include red dune sand (RS), fly ash (FA), and quarry fines (QF). Plastic LLDPE aggregate samples were mixed at either $30 \%$ and $50 \%$ by weight with the three different filler types to manufacture the PLA, resulting in the production of six different samples of LLDPE-based PLA. Details about the LLDPE-based PLA composition of the matter are described in Alqahtani and Zafar [28]. Moreover, the design of the concrete mix in accordance with the American Concrete Institute (ACI )211.2-98 is described in Alqahtani et al. [29].

The detailed mechanical properties of the LLDPE-based light-weight aggregate are described in Alqahtani et al. [27-30]. This research is not intended to focus on material properties, but rather on how the use of processed lightweight aggregates as a total replacement for coarse aggregates in lightweight concrete applications can enhance the sustainability of concrete buildings, measured in terms of LEED scoring. However, a non-comprehensive account of the results of the experimental studies conducted by Alqahtani et al. [27-30] on LLDPE-based light-weight aggregate signifies a reduction in density and compressive strength, as the replacement percentage of PLA is increased. This inverse relationship can be related to the hydrophobic properties of the recycled plastic material, which results in weakened bonding strength between the cement and LLDPE-based light-weight aggregates. At the same temperature levels, the increase in the curing temperature reduced the 28-day compressive strength of the processed lightweight aggregate concrete, in comparison with natural lightweight aggregate concrete. In addition, the high ductility of the incorporated plastic yielded higher Poisson's ratio values, in comparison with both natural lightweight aggregate and Lytag aggregate concrete. Similarly, it was noticed that the values of thermal 
conductivity of concrete incorporating processed lightweight aggregates was higher for saturated and dry conditions, as compared to natural light weight aggregate concrete.

In light of the conclusions drawn from the studies by Alqahtani et al. [27-30], concrete incorporating LLDPE-based light-weight aggregates has shown its potential utilization as an alternative source of sustainable aggregates in lightweight concrete applications, where ductile behavior, low strength, low density, and high insulation features are required. Such applications include pavements, paths, and backfill in utility trenches [29]. Other studies have proposed the potential uses of processed lightweight aggregate concrete as partition materials, floor tiles [31], façade elements, non-structural concrete panels, riverbank protection walls, and temporary shelters [32].

\section{Goal and Objectives}

The goal of this research is to explore the potential benefits that processed lightweight aggregates (PLA) can provide to a project seeking Leadership in Energy and Environmental Design (LEED) certification in accordance with the requirements of LEED v4 for Building Design and Construction. The selected light weight aggregate (LWA) material for the study is that of Alqahtani et al. [27] which is based on LLDPE, because of its high environmental benefits, low density (thus lower loads and smaller concrete volume), and high strength relative to other types of LWA. The focus is geared towards specifically recycled plastic made from linear low-density polyethylene (LLDPE) patented by Alqahtani et al. [27] as a continuation of the research stream involving that material.

The objectives are to: (1) determine which LEED credit requirements can be met through using the studied material; (2) provide a comprehensive analysis of the applicable attainable LEED credits, given the existing technical information of the selected material, and (3) provide guidelines to maximize further credit attainment. This is the first study of its kind to investigate the improved sustainability performance of recycled plastic aggregates from a LEED certification point of view to support sustainable development in the construction industry. Furthermore, this provides a quantifiable assessment of the sustainability of the LLDPE-based light-weight aggregates; and can directly be utilized in the industry in the LEED certification of new buildings. Moreover, the guidelines provided by the research will enable developers to attain higher LEED scores; thus, maximizing the financial and environmental benefits of their buildings.

\section{The Role of Recycled Plastic Aggregates towards a Sustainable Construction Industry}

With the surging realization that the construction industry is a significant contributor to the unsustainable development path of the natural environment, in addition to the associated implications for the social, economic, cultural, and political facets of sustainability, emerged the general agreement that the construction industry requires a major transformation to play an active and efficient role in sustainable development [33]. The broad consensus is further supported by the large volume of published studies identifying the different sustainable development goals (SDGs) where the construction industry can have an active contribution [34,35]

The World Green Building Council, a global network leading the sustainable transformation of the built environment, has concluded that sustainable constructions have a direct contribution towards 9 of the 17 SDGs. These include: SDG \#3 (target that emphasizes the improvement sustainable buildings bring to the human health and well-being); SDG \#7 (target that focuses on the role sustainable buildings have on the growth opportunities of the renewable energy sector); SDG \#8 (target that highlights the sustainable construction as a driver for job opportunities and economic growth); SDG \#9 (target that highlights the potential of sustainable buildings to provide resilient infrastructure systems); SDG \#11 (target that focuses on the paradigm shift sustainable buildings bring towards the creation of sustainable and thriving communities; SDG \#12 (target that addresses the minimization of construction waste and the application of sustainability management buildings); SDG \#13 (target that highlights the potential of sustainable buildings to significantly reduce 
greenhouse gas emissions); SDG \#15 (target that emphasizes the sustainable buildings' commitment to promote the biodiversity of ecosystems, and sustainably manage forests); and SDG \#17 (target that highlights the sustainable buildings' potential to create global partnerships) [36].

The sustainability attributes of processed lightweight aggregates (PLA) contribute towards the sustainable development of the construction and infrastructure industry and address several of the aforementioned SDGs as illustrated in Table 1. In other words, Table 1 provides a mapping of the use of processed lightweight aggregates (PLA) to the relevant sustainable development goals (SDGs).

Table 1. Processed lightweight aggregate (PLA) sustainability attributes contribution to the sustainable development goal (SDG) targets.

\begin{tabular}{|c|c|c|}
\hline SDGs Target & & Processed Lightweight Aggregates Sustainability Attribute \\
\hline$\# 7$ & 7.1 & $\begin{array}{l}\text { The low values of thermal conductivity of PLA for dry conditions makes it suitable for use in } \\
\text { countries that require high thermal insulation, ultimately reducing the energy and costs associated } \\
\text { with heating and cooling, in addition to the costs of incorporating materials with high thermal } \\
\text { insulation properties in concrete. This is in accordance with the plans to double the improvement } \\
\text { levels in energy efficiency on a global level. }\end{array}$ \\
\hline \multirow[t]{2}{*}{$\# 8$} & 8.1 & $\begin{array}{l}\text { The sourcing of linear low-density polyethylene (LLDPE) from a local supplier, and red dune sand } \\
\text { (RS) and quarry fines (QF) from within the Riyadh region creates jobs and helps grow the economy } \\
\text { in local areas. }\end{array}$ \\
\hline & 8.2 & $\begin{array}{l}\text { The development of improved methods to reuse waste products creates jobs and fosters innovation } \\
\text { in the R\&D sector. }\end{array}$ \\
\hline$\# 9$ & 9.1 & $\begin{array}{l}\text { The research and development }(\mathrm{R} \& \mathrm{D}) \text { process of alternative construction materials such as the } \\
\text { constituent materials of the PLA comprised of LLDPE as the binder material, and granular waste } \\
\text { such as RS, FA, or QF as the filler material is a drive towards the technological advancement in the } \\
\text { industrial sector. }\end{array}$ \\
\hline \multirow{5}{*}{ \#12 } & 12.1 & $\begin{array}{l}\text { The use of PLA reduces the demand for natural aggregates in the construction sector and is in } \\
\text { accordance with the plans for resource efficiency in consumption and production in the } \\
\text { construction industry. }\end{array}$ \\
\hline & 12.2 & $\begin{array}{l}\text { The decreased unit weight of PLA compared to conventional light weight aggregates (LWA) leads to } \\
\text { reduced } \mathrm{CO}_{2} \text { emissions as lighter materials result in smaller element sections which ultimately } \\
\text { require less cement, which is in } \\
\text { accordance with agreed frameworks to reduce adverse impacts on human health and } \\
\text { the environment. }\end{array}$ \\
\hline & 12.3 & $\begin{array}{l}\text { The mitigation of landfill concerns resulting from the sustainable use of plastic wastes as alternative } \\
\text { construction materials is in accordance with agreed frameworks to reduce adverse impacts on } \\
\text { human health and the environment. }\end{array}$ \\
\hline & 12.4 & $\begin{array}{l}\text { The mitigation of environmental and economic problems associated with sandstorms in specific } \\
\text { countries resulting from the use of red dune sand as a filler is in accordance with agreed frameworks } \\
\text { to reduce adverse impacts on human health and the environment. }\end{array}$ \\
\hline & 12.5 & $\begin{array}{l}\text { The reduced amount of water needed in the concrete mix due to the lower water absorption of PLA } \\
\text { addresses the goal to achieve sustainable management and the efficient use of natural resources } \\
\text { by } 2030 \text {. }\end{array}$ \\
\hline \#13 & 13.1 & $\begin{array}{l}\text { The sourcing of linear low-density polyethylene (LLDPE) from a local supplier, and red dune sand } \\
\text { (RS) and quarry fines (QF) from within the Riyadh region reduces the costs and carbon emissions } \\
\text { associated with the transportation of materials. }\end{array}$ \\
\hline
\end{tabular}

\section{LEED Certification in the Construction Industry}

\subsection{The LEED Certification System}

The U.S. Green Building Council (USGBC) is a non-profit organization established in 1993, with a commitment towards the development of sustainable buildings, communities, and neighborhoods based on the promotion of strategies which protect human health, 
reduce adverse environmental impacts, and support economic growth [37]. The USGBC has described the global best practices for the sustainable design, construction and operation of built environments through their Leadership in Energy and Environmental Design (LEED); the world's most widely used green building certification program in the industry. The first LEED pilot version was released by the USGBC in 1998, as its principal vehicle to promote sustainable design and construction. The LEED rating system assesses eight areas (shown in Figure 1): sustainable sites, water efficiency, energy and atmosphere, materials and resources, indoor environmental quality, innovation in design, and regional priority. The LEED reference guide can be applied to a plethora of building types, and as such includes different rating systems depending on the intended use, including commercial spaces, medical office buildings, retail centers, warehouses, educational institutions, residential spaces, existing buildings, and mixed-use developments.

Figure 1 shows the areas (or categories) of the LEED rating system and the corresponding credits that can be attained. Each credit has a maximum number of points that can be achieved. For example, the credit named "Reduced Parking Footprint" is worth one point. The total number of attainable points is 110 . For a building to be LEED certified, it must attain at least 40 points. Buildings with 50 to 59 points have the Silver status. Those with 60 to 79 have the Gold status, and those with higher than 80 points have the Platinum status. Generally, project managers (or developers) can pick and choose the credits they want to pursue, based on the conditions of their projects. However, in order to be certified, certain prerequisites must be met. Buildings not meeting those prerequisites are not certified no matter how many points they attain. The USGBC has publications detailing how to attain each point. El-adaway and Truax [38] provided a summarized demonstration of the point attainment that led to the LEED certification of an educational building.

\subsection{Benefits of Certifying Buildings with LEED}

In recent years, a large volume of published studies has discussed the benefits of LEED certification in the construction industry based on simulated and actual case studies. A study by Diana Zheng [40] reported the use of LEED energy models to compare the post-occupancy energy use from three LEED certified buildings at UC Berkley with conventional buildings. Results concluded a lower energy consumption in two of the three cases compared to the energy model simulations for the projected energy performance of conventional buildings. Similarly, another study was conducted to compare the water and electrical energy usage, and construction and operational costs if an existing conventional educational building at Bogotá, Colombia was to be transformed to meet the required design parameters of LEED certification [41]. Results indicate a $42.70 \%$ and $31.24 \%$ reduction in water and energy consumption respectively for the modified design compared to the existing case study [41]. Another economic benefit is reflected by a further study which presented a $5.80 \%$ higher commercial rent per square foot for a LEED certified commercial building in the United States compared to a conventional non-LEED certified building [42].

There is a considerable amount of literature on the benefits of the implementation of sustainable construction (SC) practices [43-45]. Sustainable construction encompasses a broad set of concepts which does not just cover the sustainable building design and materials, but extends to include the utilized products, resources, installed appliances, incorporated technologies and strategies, and the implemented construction methods over the entire life cycle of the building. Therefore, SC involves an integrative decisionmaking process in every stage of the construction project, from the early planning, design, construction, operation, and maintenance, up to the project demolition based on the social, economic, and environmental factors and impacts. Most recent studies emphasize the direct impact the construction industry has on human well-being, economic performance, and environmental conditions [46], with the greatest influence on sustainability in comparison with any other industrial sector [47]. 
LEED v4 for BD+C: Core and Shell

Project Checklist

Project Name:

Date:

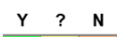

Credt Integrative Process

$0 \quad 000$ Location and Transportation

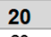

\begin{tabular}{|c|c|c|}
\hline & credt & LEED for Neighborhood Development Location \\
creat & Sensitive Land Protection \\
\hline & credt & High Priority Site \\
\hline & creat & Surrounding Density and Diverse Uses \\
\hline & credt & Access to Quality Transit \\
\hline & credt & Bicycle Facilities \\
\hline & credt & Reduced Parking Footprint \\
\hline & credt & Green Vehicles
\end{tabular}

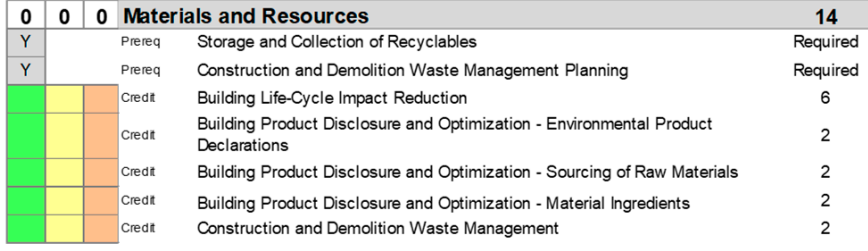

\begin{tabular}{|l|l|l|l|}
\hline $\mathbf{0}$ & $\mathbf{0}$ & $\mathbf{0}$ & Sustainable Sites \\
\hline Y & & Prereq & Construction Activity Pollution Prevention \\
& & credt & Site Assessment \\
\hline & & credt & Site Development - Protect or Restore Habitat \\
& credt & Open Space \\
\hline & credt & Rainwater Management \\
\hline & credt & Heat Island Reduction \\
\hline & creat & Light Pollution Reduction \\
\hline & credt & Tenant Design and Construction Guidelines \\
\hline
\end{tabular}

\begin{tabular}{|c|c|c|c|c|}
\hline 0 & \multirow[t]{3}{*}{$\begin{array}{lll}0 & 0 \\
\end{array}$} & \multirow{2}{*}{$\begin{array}{l}\text { Indoor } \\
\text { Prereq }\end{array}$} & \multirow{2}{*}{$\begin{array}{l}\text { r Environmental Quality } \\
\text { Minimum Indoor Air Quality Performance }\end{array}$} & \multirow{2}{*}{$\begin{array}{l}10 \\
\text { Required }\end{array}$} \\
\hline $\mathrm{Y}$ & & & & \\
\hline Y & & Prereq & Environmental Tobacco Smoke Control & Required \\
\hline & & creatt & Enhanced Indoor Air Quality Strategies & 2 \\
\hline & & credit & Low-Emitting Materials & 3 \\
\hline & & Credt & Construction Indoor Air Quality Management Plan & 1 \\
\hline & & Credt & Daylight & 3 \\
\hline & & Credit & Quality Views & 1 \\
\hline
\end{tabular}

\begin{tabular}{l|l|lll}
0 & 0 & 0 & Water Efficiency & 11
\end{tabular}

\begin{tabular}{|l|lll|}
\hline $\mathrm{Y}$ & Prereq & Outdoor Water Use Reduction & Required \\
\hline $\mathrm{Y}$ & Prereq & Indoor Water Use Reduction & Required \\
\hline $\mathrm{Y}$ & & P & Requ \\
\hline
\end{tabular}

Prereq Building-Level Water Metering

Outdoor Water Use Reduction

Indoor Water Use Reduction

Cooling Tower Water Use

credt Water Metering

\begin{tabular}{|l|l|lll|}
\hline $\mathbf{0}$ & $\mathbf{0}$ & $\mathbf{0}$ & Innovation \\
\hline & & & credt & Innovation \\
& & & Credt & LEED Accredited Professional \\
\hline
\end{tabular}

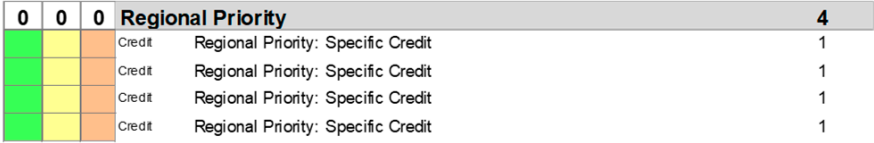

\begin{tabular}{|c|c|c|c|c|}
\hline 0 & 0 & \multicolumn{2}{|c|}{ Energy and Atmosphere } & 33 \\
\hline Y & & Prereq & Fundamental Commissioning and Verification & Required \\
\hline Y & & Prereq & Minimum Energy Performance & Required \\
\hline Y & & Prereq & Building-Level Energy Metering & Required \\
\hline Y & & Prereq & Fundamental Refrigerant Management & Required \\
\hline & & credt & Enhanced Commissioning & 6 \\
\hline & & Credt & Optimize Energy Performance & 18 \\
\hline & & credt & Advanced Energy Metering & 1 \\
\hline & & credt & Demand Response & 2 \\
\hline & & credt & Renewable Energy Production & 3 \\
\hline & & credt & Enhanced Refrigerant Management & 1 \\
\hline
\end{tabular}

\begin{tabular}{|l|l|l|lcl}
\hline 0 & 0 & 0 & TOTALS & Possible Points: 110
\end{tabular}

Certified: 40 to 49 points, Silver: 50 to 59 points, Gold: 60 to 79 points, Platinum: 80 to 110

Figure 1. The Leadership in Energy and Environmental Design (LEED) Scorecard [39].

\section{Research Methodology}

This research takes an inductive reasoning approach through which extensive data are analyzed to establish clear links with the research objectives. First, the sustainability aspects of processed lightweight aggregates are identified; mainly from the findings of Alqahtani, as this paper is a continuation of a series of preceding papers and patents which address the physical and mechanical properties of concrete incorporating processed lightweight aggregates and granular waste as a filler material. Second, the categories in LEED for Building Design and Construction (LEED BD+C) rating system are analyzed in order to assess the applicable credits. Third, guidelines are provided to maximize credit attainment according to available technical data. Fourth, recommendations are made for further credit attainment. Figure 2 shows a summary of the research methodology. 


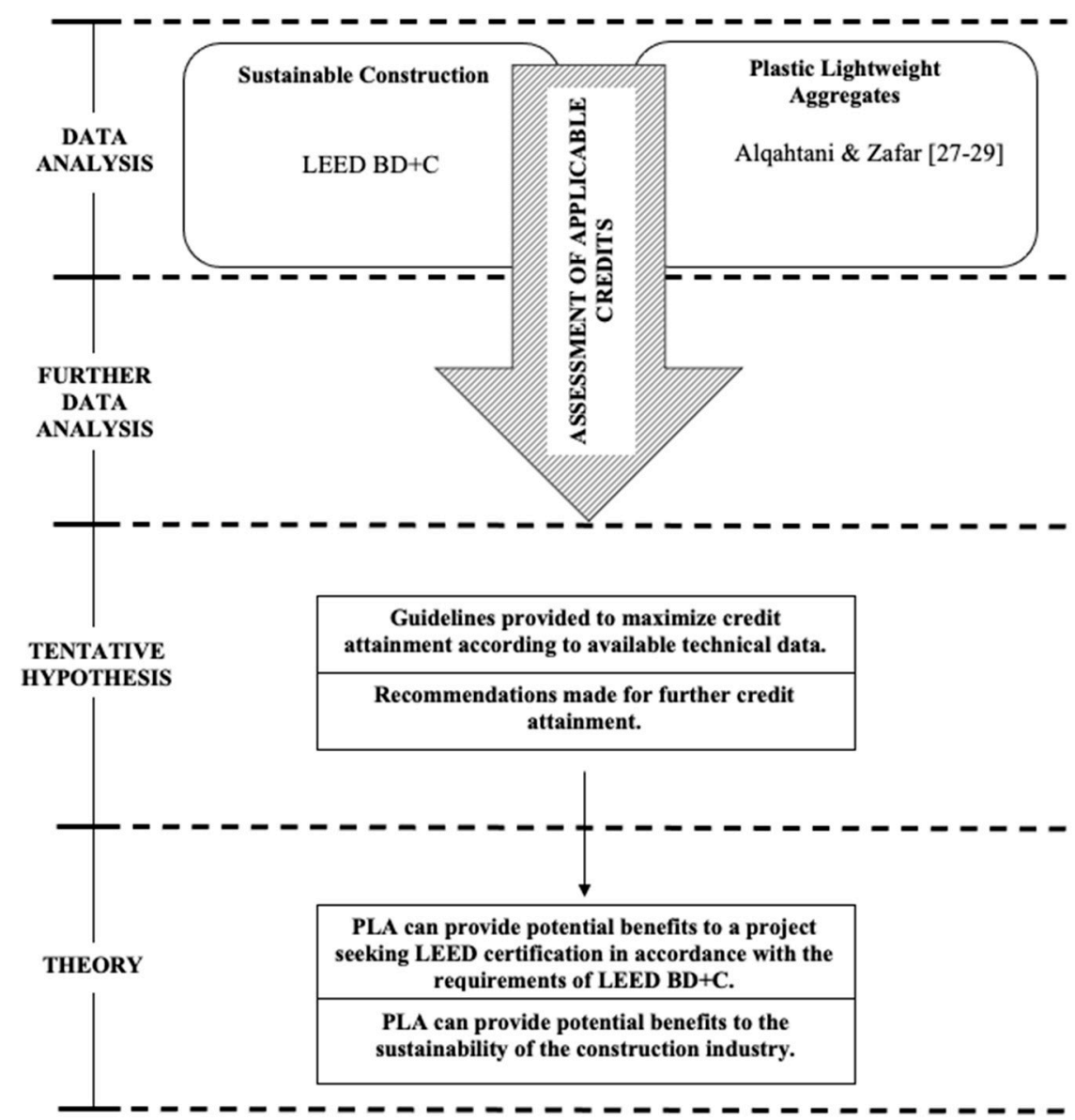

Figure 2. Research methodology.

\section{Sustainability Evaluation of Processed Lightweight Aggregates}

LEED points are not earned for the use of a particular sustainable building material or product, but the use of PLA as a total replacement for coarse aggregates in lightweight concrete applications would contribute to earning points towards LEED certification based on the following guiding parameters:

- Constituent polymers and fillers used to produce PLA are readily available.

- The mitigation of landfill concerns and global carbon emissions resulting from the sustainable use of plastic wastes as alternative construction materials.

- The mitigation of environmental and economic problems associated with sandstorms in specific countries resulting from the use of red dune sand as a filler.

- The reduced overall weight of the final building structure results in cost savings, according to the life cycle cost analysis (LCCA).

- The decreased unit weight of PLA compared to conventional light weight aggregates (LWA) leads to reduced $\mathrm{CO}_{2}$ emissions as lighter materials result in smaller element sections which ultimately require less cement.

- The reduced demand for natural aggregates in the construction sector.

- The reduced amount of water needed in the concrete mix due to the lower water absorption of PLA.

- The low values of thermal conductivity of PLA for dry conditions makes it suitable for use in countries that require high thermal insulation, ultimately reducing the energy and costs associated with heating and cooling, in addition to the costs of incorporating materials with high thermal insulation properties in concrete.

The aforementioned attributes of the PLA are recognized by LEED mainly in the "Materials and Resources" category, but can also earn points in the "Innovation" category, 
as illustrated in Table 2. The prerequisites are not worth any points, but they must be achieved prior to addressing any of the credits in each category.

Table 2. LEED points attainable by the use of PLA in concrete.

\begin{tabular}{|c|c|c|c|}
\hline Category & $\begin{array}{c}\text { Prerequisite/ } \\
\text { Credit }\end{array}$ & Credit Title & Maximum Attainable LEED Points \\
\hline \multirow{4}{*}{ Materials and Resources } & Prerequisite & Storage and Collection of Recyclables & $\mathrm{N} / \mathrm{A}$ \\
\hline & Credit 1 & Building Life-Cycle Impact Reduction & 4 \\
\hline & Credit 2.2 & Building Product Disclosure and Optimization-Sourcing of Raw Materials & 2 \\
\hline & Credit 2.3 & Building Product Disclosure and Optimization-Material Ingredients & 1 \\
\hline Innovation & Credit 1 & Innovation & 1 \\
\hline
\end{tabular}

\subsection{Materials and Resources (MR) Category}

The prerequisites and credits of this category are designed to reduce the potential environmental impact of materials throughout its life cycle, recognize the inclusion of solutions which promote resource efficiency, and focus on construction and demolition waste reduction and recycling. The category has two prerequisites and three credits; one of which is further divided into three sub-credits. Each requirement is devised to promote the life-cycle approach through the identification of specific activities responsible for the reduction of embodied carbon during the entire construction lifecycle.

\subsubsection{Prerequisite 1: Storage and Collection of Recyclables}

This prerequisite is intended to reduce the amount of solid waste generated by building occupants, ultimately decreasing the amount of solid waste disposed of in landfills.

\section{Technical Review}

There is no direct relation between the use of PLA as a replacement for coarse aggregates in concrete and this prerequisite, as its requirements are directed towards the facilitation of recycling options and activities for building occupants. However, a connection to the use of PLA can be made in the submission of the project's recycling approach narrative, given that the synthetic aggregate used in concrete is a composite material comprised of between $30 \%$ and $50 \%$ of recycled plastic, a main constituent of both the project's waste stream and building component.

\section{Potential Strategies}

Dedicated areas for the storage and collection of recyclable materials are to be provided based on the overall building square footage. In addition, an assessment of existing local recycling programs is essential to determine the optimum diversion method of the recyclable materials from the buildings' waste streams to the off-site waste management areas. No calculations are required for this prerequisite to verify compliance, however it is essential to provide a narrative which confirms that waste collection areas in the building are easily and fully accessible by building occupants and haulers through the provision of the building floor plans. In addition, a description of the waste streams audit is to be provided describing the types of waste materials being collected for recycling. Instructions are to be also given to occupants on recycling procedures, and an optional narrative can be provided to building occupants identifying the project's recycling underlying concept and approach. This constituent, despite being non-compulsory, is necessary in this case, as it could provide useful insight to building occupants and maintenance personnel on the amount and type of recycled plastics which would contribute to the construction of the building's main building blocks. Given that research findings specify that the synthetic aggregate used in concrete is a composite material comprised of between 30\% and $50 \%$ plastic which can include different types of plastic including linear low-density 
polyethylene (LLDPE), low-density polyethylene (LDPE), high-density polyethene (HDPE), and polypropylene [27].

\subsubsection{Credit 1: Building Life Cycle Impact Reduction}

This credit is intended to encourage project teams to improve the environmental performance of products and materials through the adoption of adaptive reuse concepts (USGBC, 2020).

\section{Technical Review}

A study was made by the authors on a small building with a floor area of $500 \mathrm{~m}^{2}$ and average column spacing of $5 \mathrm{~m}$. The building was once structurally designed using concrete with traditional aggregates, and designed one more time assuming the LLDPE-based PLA was used for the slabs while keeping the columns and footings with traditional concrete. Although the LLDPE-based PLA results in reduction in the concrete strength relative to the traditional aggregates, it has lower density which leads to lower loads to begin with. The strength of the concrete using the LLDPE-based PLA was $18 \mathrm{MPa}$ (as described in Alqahtani and Zafar [28], and that of the traditional concrete was $25 \mathrm{MPa}$.

Based on the study, it was found that the use of LLDPE-based PLA resulted in a percentage reduction in the total concrete and steel quantities as shown in Table 3. The scenario names are defined in the format (type of aggregates-avg. slab span-no. of floors). Correspondingly, Scenario N-3-G2 denotes the use of natural aggregates-3 $3 \times 3 \mathrm{~m}$ average slab span-ground floor and two floors.

Table 3. Scenario structures for life-cycle cost analysis.

\begin{tabular}{ccc}
\hline SCENARIO Name * & Concrete Quantities (Y) ${ }^{3}$ ) & Steel Quantities (kg) \\
\hline SCENARIO N-3-G2 & 521 & 19,824 \\
SCENARIO L-3-G2 & 521 & 19,824 \\
SCENARIO N-4-G2 & 625 & 22,051 \\
SCENARIO L-4-G2 & 609 & 21,475 \\
SCENARIO N-5-G2 & 653 & 21,196 \\
SCENARIO L-5-G2 & 611 & 20,400 \\
SCENARIO N-6-G2 & 816 & 27,657 \\
SCENARIO L-6-G2 & 786 & 26,492 \\
SCENARIO N-3-G3 & 727 & 28,496 \\
SCENARIO L-3-G3 & 716 & 28,432 \\
SCENARIO N-4-G3 & 900 & 31,227 \\
SCENARIO L-4-G3 & 853 & 29,665 \\
SCENARIO N-5-G3 & 895 & 30,437 \\
SCENARIO L-5-G3 & 852 & 28,251 \\
SCENARIO N-6-G3 & 1102 & 39,421 \\
SCENARIO L-6-G3 & 1054 & 38,669 \\
SCENARIO N-3-G10 & 2206 & 136,517 \\
SCENARIO L-3-G10 & 2206 & 131,069 \\
SCENARIO N-4-G10 & 2626 & 169,011 \\
SCENARIO L-4-G10 & 2589 & 158,483 \\
SCENARIO N-5-G10 & 2766 & 119,908 \\
SCENARIO L-5-G10 & 2566 & 130,001 \\
SCENARIO N-6-G10 & 3417 & 155,231 \\
SCENARIO L-6-G10 & 3311 & 153,096 \\
\hline
\end{tabular}

* G\# $\rightarrow$ \# represents the number of floors plus the ground floor. $\mathrm{N} \rightarrow$ traditional concrete (strength $=25 \mathrm{MPa}$, density $=2400 \mathrm{~kg} / \mathrm{m}^{3}$ ). L $\rightarrow$ The slabs are made of the linear low-density polyethylene (LLDPE)-based PLA (strength $=18 \mathrm{MPa}$, density $=1800 \mathrm{~kg} / \mathrm{m}^{3}$ ), but the columns and foundations are made of traditional concrete. L-\#-G or N-\#-G $\rightarrow$ \# represents the average slab span.

As illustrated in Figure 3, the maximum reduction in concrete quantities of $7.23 \%$ was found for a 10-story building with an average slab span of $5 \times 5 \mathrm{~m}$ where the maximum reduction in steel quantities of $7.18 \%$ was found for a 3-story building with an average slab 
span of $5 \times 5 \mathrm{~m}$. Further findings of the conducted study demonstrated savings in both the construction and end of life costs of $7 \%$ and $22 \%$, respectively, for the use of LLDPE-based PLA in comparison with natural aggregates. The savings in the end of life costs are due to the reduced concrete density of LLDPE-based PLA, which results in a decreased landfill cost, as the density is a governing factor in the cost of disposal to landfill.

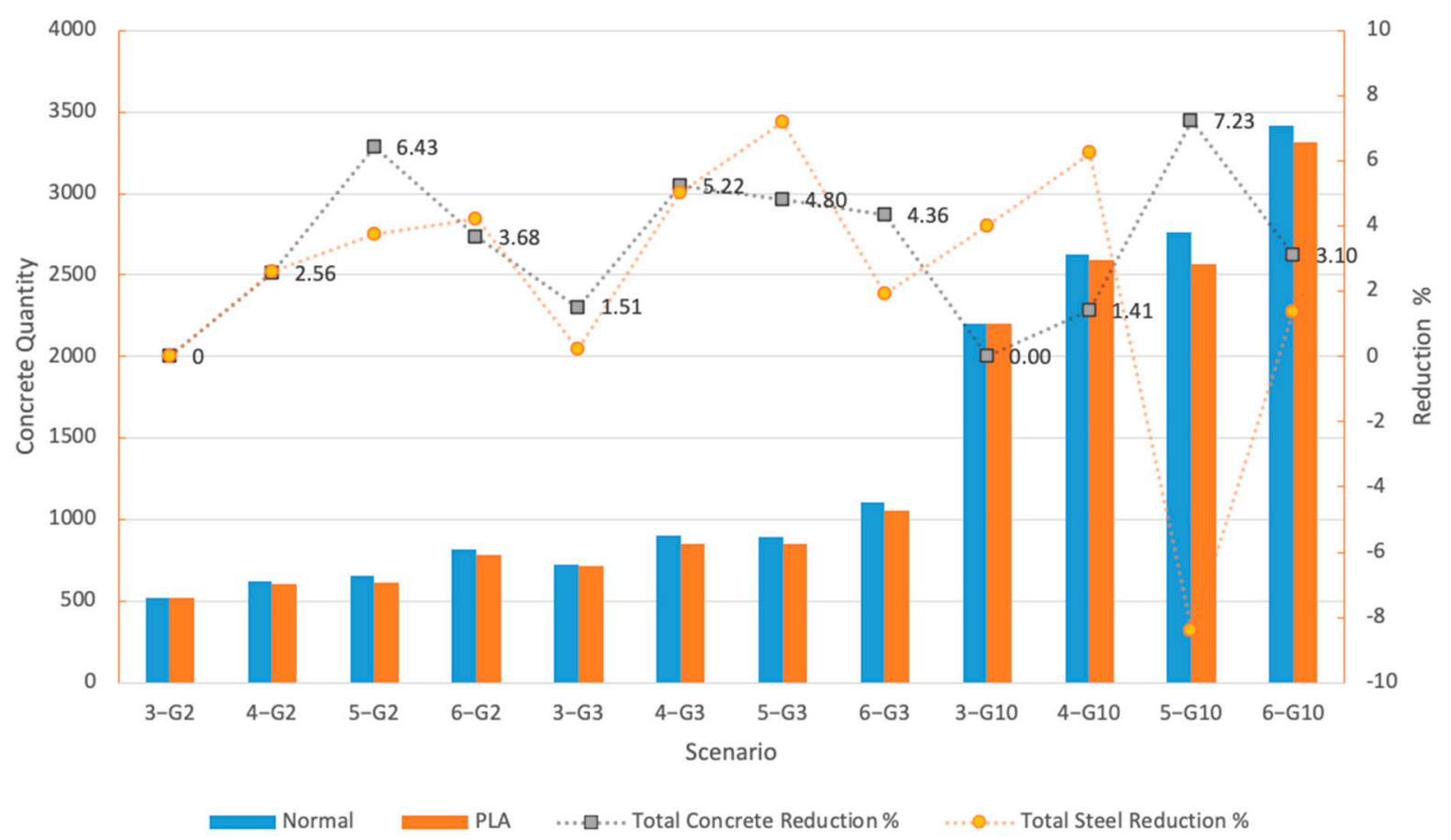

Figure 3. Reductions in concrete and steel quantities.

\section{Potential Strategies}

The life cycle assessment of the building structure could be conducted using Option 4 . To achieve 1 point, a compliant life cycle assessment (LCA) is to be conducted for the building structure made using concrete with PLA, and documented in a whole building life cycle assessment (WBLCA) report, in addition to an analytical summary which describes the differences between the baseline and proposed building and the related LCA results. There are two other suitable pathways, for 2 and 3 points each, which similar to path 1 , require the WBLCA analysis. However, the additional points can only be achieved given the presence of a percentage reduction of $5 \%$ or $10 \%$ for three of six listed environmental impact categories; one of which must be global warming potential $\left(\mathrm{kg} \mathrm{CO}_{2} \mathrm{e}\right)$. The other two categories which can be addressed by the use of structural concrete with PLA are both the formation of tropospheric ozone ( $\mathrm{kg} \mathrm{NOx} / \mathrm{kg} \mathrm{O}_{3} / \mathrm{kg}$ ethene) and the depletion of nonrenewable energy resources [megajoule(MJ) using the Center of Environmental Studeis (CML) methodology/depletion of fossil fuels using the Tool for the Reduction and Assessment of Chemical and other environmental Impacts(TRACI) methodology].

\subsubsection{Credit 2.2: Building Product Disclosure and Optimization—Sourcing of} Raw Materials

This credit is intended to encourage project teams to select products and materials confirmed to have been extracted or sourced in a responsible manner (USGBC, 2020).

\section{Technical Review}

The basic materials used to produce PLA include a recycled polyethylene based plastic product, such as linear low-density polyethylene (LLDPE) used as the binder material and provided by a local supplier. In addition to the filler material, which includes granular 
waste such as red dune sand (RS), fly ash (FA), or quarry fines (QF) (Alqahtani and Zafar, 2020). Research findings also indicate that the powdered form of plastic LLDPE is provided by a local supplier who collects and treats all types of discarded plastics within the vicinity of the local area [29].

\section{Potential Strategies}

The responsible sourcing and extraction criteria are composed of five components as identified by the USGBC; extended producer responsibility, bio-based materials, wood products, materials reuse, and recycled content [48]. The use of PLA as a total replacement for coarse aggregates in lightweight concrete applications would contribute to earning LEED points with regards to the recycled content component. However, to earn one or two points, products are to be sourced from at least three or five different manufacturers respectively, that meet at least one of the aforementioned responsible sourcing and extraction criteria. The submittal requirements for this credit include the documentation of the material claims, and the building product disclosure and optimization calculator; which must be fed with the following information by the project manager or developer:

- Material Information Data

Description of each material in the utilized PLA

Is the material structure or enclosure? (for each material)

Name of the manufacturer (for each material)

Material cost (for each material)

Total value of sustainable materials

Total material cost

- $\quad$ Building Product Disclosure and Optimization Calculator-Sourcing of Raw Materials

Recycled Content

- Percent post-consumer $(\%)$

- Percent pre-consumer $(\%)$

- Sustainable criteria value (\$)

Does the entire product meet local criteria?

Total sustainable criteria value with location valuation factor (\$)

The extraction, manufacturing, and purchasing of the materials within the local vicinity is to be included in the credit achievement calculation, where the "local criteria" is met for products sourced within $160 \mathrm{~km}$ of the project site.

With regard to the detailed material data pertaining to the four basic materials of PLA, linear low-density polyethylene (LLDPE) as the polymer binding agent is considered a post-consumer recycled material, since it consists of waste plastic packaging material from the Saudi Basic Industries Corporation (SABIC) company, whereas red dune sand (RS), fly ash (FA), and quarry fines (QF) are pre-consumer recycled materials. LLDPE, RS, and QF meet the local criteria since they are sourced within the Riyadh region, at 30, 25, and $40 \mathrm{~km}$ respectively of the project site (assuming that the project site is in Riyadh city). However, FA does not meet local criteria, since the utilized FA class F is an imported waste product.

\subsubsection{Credit 2.3: Building Product Disclosure and Optimization-Material Ingredients}

This credit is intended to encourage project teams to select products for which there are chemical inventories of their constituent ingredients, and the products are verified to reduce the usage and generation of hazardous substances. In addition, it is intended to reward project teams which develop products with favorable life cycle impacts in terms of environmental, social, and economical aspects (USGBC, 2020).

\section{Technical Review}

The synthetic aggregate with a maximum particle size of $10 \mathrm{~mm}$ contains between $30 \%$ and 50\% recycled shredded LLDPE plastic, which encapsulates the filler material [27]. The filler material is comprised of different granular wastes including red dune sand (RS), fly 
ash (FA), or quarry fines (QF). Statistics on the production of plastic waste materials signify the high percentage contribution of polyethylene-based products of approximately $29 \%$ to the total amount of waste plastic [49]; of which plastic solid waste represents and average of $10 \%$ of the amount of solid waste generated on a global level [50]. The sustainable use of plastic wastes as alternative construction materials is an effective solution for processing plastic wastes, as it mitigates the social, economic, and environmental impacts associated with the recycling of plastic. As it stands, acid rain arises from the toxic emissions released from the incineration of plastic waste [51]. In addition, the disposal of plastic wastes in open fields causes the contamination of surface soils and decreases the amount of available landfill spaces [52]. From another point, there is no competitive advantage which drives the demand for recycled products, as the prices of virgin raw materials are less than the cost of products produced from recycled plastic waste streams due to the additional cost of recycling.

Similarly, the sustainable utilization of fly ash, red dune sand, or quarry fines as a partial replacement of cement in concrete has notable impacts on the reduction of environmental pollution, and the conservation of land, finite resources, and human health. The proportions of the fly ash fill material used in the study is mixed at amounts of $70 \%$ or 50\% with the LLDPE to form the homogenous mixture [28]. Fly ash is the unburned byproduct residue released from the coal combustion process in electric power generating plants [53]. Moreover, the composition of fly ash, including silica, alumina, and other oxide materials classify fly ash as a hazardous material, which requires adequate waste management [54]. From an economic standpoint, fly ash has a notable influence on the reduced water demand of cement mortar [55] in addition to the reduced amount of cement required in concrete as a result of the favorable pozzolanic properties of fly ash [56], as well as the related embodied $\mathrm{CO}_{2}$ emissions [57].

In locations such as the coastal regions of Saudi Arabia [58], where red dune sand is readily available in copious amounts, its use in the construction industry addresses associated economic and environmental problems to some extent, as the sand hinders further developmental plans in the area and due to its dynamic nature it would affect air quality and lead to dust storms [58]. Moreover, quarry fines are produced as a residual by-product of quarrying activities including the crushing and washing processes of coarse aggregates [59].

\section{Potential Strategies}

The use of PLA as a total replacement for coarse aggregates in lightweight concrete applications would contribute to earning LEED points using Option 2. material ingredient optimization, through which material ingredients are assessed based on all six properties of the "Manufacturer Inventory" program demonstrated in Table 4.

Table 4. Material ingredient optimization-manufacturer inventory or Health Product Declaration (HPD).

\begin{tabular}{|c|c|c|c|c|c|c|}
\hline Material & $\begin{array}{l}\text { The product has } \\
\text { demonstrated a } \\
\text { chemical inventory to } \\
\text { at least } 0.01 \% \text { by } \\
\text { weight }(100 \mathrm{ppm}) \text {. }\end{array}$ & $\begin{array}{l}\text { At least } 95 \% \text { by weight } \\
\text { of product is assessed } \\
\text { using GreenScreen } \\
\text { Benchmark assessment. }\end{array}$ & $\begin{array}{l}\text { No Benchmark } 1 \\
\text { hazards (BM-1) are } \\
\text { present in the end } \\
\text { use product. }\end{array}$ & $\begin{array}{l}\text { The remaining } 5 \% \text { by } \\
\text { weight of product not } \\
\text { assessed has been } \\
\text { inventoried and screened } \\
\text { using GreenScreen List } \\
\text { Translator. }\end{array}$ & $\begin{array}{l}\text { No GreenScreen LT-1 } \\
\text { hazards are present in } \\
\text { the end use product. }\end{array}$ & $\begin{array}{l}\text { The documents } \\
\text { must be third } \\
\text { party verified. }\end{array}$ \\
\hline
\end{tabular}

\subsection{Innovation Category}

The credits of this category are intended to encourage project teams to achieve outstanding or innovative performance. There is a total of five innovation points available for this category which can be attained through three different paths. The current technical properties of PLA enable it to pursue LEED points in the first "innovation" option worth 
1 point. This is achieved when the project demonstrates the use of a strategy that is not addressed in the LEED green building rating system, and can demonstrate a significant, measurable improvement in environmental performance. The second "pilot" option worth 1 point is achieved through the implementation of any of the pilot credits defined in the USGBC's LEED Pilot Credit Library. The third "additional strategies" option worth up to 3 points, is achieved by achieving no more than two "exemplary performance" credits, which are awarded for realizing either double the credit requirements or the subsequent percentage threshold for an existing LEED prerequisite or credit. However, to achieve all 5 possible points, the project team should attain at least one "innovation" credit, at least one "pilot" credit, and a maximum of two "exemplary performance" credits.

\section{Technical Review}

This credit is intended to encourage project teams to conserve natural resources and associated energy consumption through the use of innovative building materials.

Design approach or strategies used to meet the requirements:

Option 1: Demonstrate the percentage of water absorption for LLDPE plastic in comparison with both manufactured and natural lightweight aggregates. In addition to the subsequent amount of water required in the concrete mix.

Or,

Option 2: Demonstrate the low values of thermal conductivity of PLA for dry conditions in comparison with both manufactured and natural lightweight aggregates. In addition, evaluate the resulting energy costs associated with heating and cooling to the costs of incorporating materials with high thermal insulation properties in concrete.

Proposed submissions to demonstrate compliance:

If Option 1 is opted for: The project manager shall provide documentation which indicates the water absorption percentage for LLPDE plastic and the correlated amount of water required in the concrete mix. This documentation is available for the LLPDEbased PLA as follows. The low percentage of water absorption for LLDPE plastic is $0.05-0.10$ [28], which ultimately results in a reduced amount of water needed in the concrete mix, in comparison to the high water absorption exhibited by concrete produced with both manufactured or natural lightweight aggregates [60]. As indicated by Alqahtani and Zafar [28], the LLDPE-based PLA has almost one fifth to half of the absorption percentage of the manufactured light-weight aggregates.

If Option 2 is opted for, the project manager shall do the following steps:

1. Step 1: Provide documentation which indicates the values of thermal conductivity of PLA for dry conditions in comparison with both manufactured and natural lightweight aggregates. This documentation is present as follows. In the study conducted by Alqahtani and Zafar [28], they concluded values of thermal conductivity of processed light weight aggregate concrete at an increased $17 \%$ and $49 \%$ for saturated and dry conditions respectively, as compared to the natural light weight aggregate concrete.

2. Step 2: Conduct an energy and cost saving evaluation associated with heating and cooling given the use of PLA with the costs of incorporating materials with high thermal insulation properties in concrete. This information is project-specific. Generally, the improved insulation properties of PLA compared to conventional aggregates in concrete leads to reduced energy costs in countries with hot weather such as the Gulf region [29]. However, a detailed study of the cost-effectiveness evaluation for the energy efficiency of PLA must be performed to attain the innovation point through this option path.

3. Step 3: Attach the received patents as a supporting document to the intent compliance. The patents are present as follows: There are two patents for the LLDPE-based PLA:

- Patent \#1: United States Patent No.: US 8,921,463 B1 Date of Patent: 30 December 2014 Invention Title: Synthetic aggregate for use in concrete 
- Patent \#2: KACST Saudi Patent No.: 3960 Date of Patent: 25 March 2015 Invention Title: Synthetic aggregate for use in concrete

\section{Discussion}

The calculation of LEED points that can be possibly earned from the use of PLA as a total replacement for coarse aggregates in lightweight concrete applications are presented in Table 5. In a further step, the potential strategies are summarized to provide a consolidated set of guidelines, by which PLA can possibly increase the overall LEED points of the whole project by an additional 8 points out of 110 . There are four possible levels of certification in the LEED: Certified (40-49) points, Silver (50-59 points), Gold (60-79 points), and Platinum (80+ points); of which the possible 8 points can allow for the potential increase of the project's certification by one level.

Table 5. Summary of potential strategies and LEED points attainable by the use of PLA in concrete.

\begin{tabular}{|c|c|c|c|c|}
\hline $\begin{array}{l}\text { Prerequisite/ } \\
\text { Credit }\end{array}$ & Category & Credit Title & $\begin{array}{l}\text { Maximum Attainable } \\
\text { LEED Points }\end{array}$ & Potential Strategies \\
\hline Prerequisite & & $\begin{array}{c}\text { Storage and Collection of } \\
\text { Recyclables }\end{array}$ & $\mathrm{N} / \mathrm{A}$ & $\begin{array}{l}\text { 1. Dedicated areas for the storage and collection of } \\
\text { recyclable materials are to be provided, based on the } \\
\text { overall building square footage. } \\
2 \text {. Narrative which confirms that waste collection areas in } \\
\text { the building are easily and fully accessible by building } \\
\text { occupants and haulers through the provision of the } \\
\text { building floor plans. } \\
3 \text {. Description of the waste streams audit, describing the } \\
\text { types of waste materials being collected for recycling. } \\
4 \text {. Instructions are to be given to occupants on recycling } \\
\text { procedures, and an optional narrative can be provided to } \\
\text { building occupants identifying the project's recycling } \\
\text { underlying concept and approach. }\end{array}$ \\
\hline Credit 1 & $\begin{array}{l}\text { Materials and } \\
\text { Resources }\end{array}$ & $\begin{array}{c}\text { Building Life Cycle Impact } \\
\text { Reduction }\end{array}$ & 4 & $\begin{array}{l}\text { 1. Compliant life cycle assessment (LCA) is to be } \\
\text { conducted for the building structure made using concrete } \\
\text { with PLA assessment (LCA), and documented in a whole } \\
\text { building life cycle assessment (WBLCA) report. } \\
\text { 2. Analytical summary which describes the differences } \\
\text { between the baseline and proposed building and the } \\
\text { related LCA results. } \\
\text { 3. Additional points can be achieved given the presence } \\
\text { of a percentage reduction of } 5 \% \text { or } 10 \% \text { for three of the six } \\
\text { listed environmental impact categories. }\end{array}$ \\
\hline Credit 2.2 & & $\begin{array}{c}\text { Building Product } \\
\text { Disclosure and } \\
\text { Optimization-Sourcing of } \\
\text { Raw Materials }\end{array}$ & 2 & $\begin{array}{l}\text { 1. Products are to be sourced from at least three or five } \\
\text { different manufacturers respectively, that meet at least } \\
\text { one of the responsible sourcing and extraction criteria. } \\
\text { 2. Documentation of the material claims, and the building } \\
\text { product disclosure and optimization calculator. } \\
\text { 3. Extraction, manufacturing, and purchasing of the } \\
\text { materials within the local vicinity is to be included in the } \\
\text { credit achievement calculation }\end{array}$ \\
\hline Credit 2.3 & & $\begin{array}{c}\text { Building Product } \\
\text { Disclosure and } \\
\text { Optimization-Material } \\
\text { Ingredients }\end{array}$ & 1 & $\begin{array}{l}\text { 1. Material ingredients meet all six properties of the } \\
\text { "Manufacturer Inventory" program. }\end{array}$ \\
\hline Credit 1 & Innovation & Innovation & 1 & $\begin{array}{l}\text { 1. Documentation which indicates the water absorption } \\
\text { percentage for LLPDE plastic and the correlated amount } \\
\text { of water required in the concrete mix. } \\
\text { 2. Documentation which indicates the values of thermal } \\
\text { conductivity of PLA for dry conditions in comparison } \\
\text { with both manufactured and natural } \\
\text { lightweight aggregates. } \\
\text { 3. Energy and cost saving evaluation is to be conducted, } \\
\text { in association with heating and cooling, given the use of } \\
\text { PLA with the costs of incorporating materials with high } \\
\text { thermal insulation properties in concrete. } \\
4 \text {. Attach the received patents as a supporting document } \\
\text { to the intent compliance }\end{array}$ \\
\hline
\end{tabular}

This paper provides a foundation for a solid sustainability assessment of PLA, its focus is to explore and analyze the sustainability attributes of PLA within the broad context of LEED certification. Recommended further studies include building on the conducted research in this paper by specifying the precise number of achievable credits, through presenting LEED calculator calculations, developing in-depth case studies, and providing 
analytical reports and detailed documentation of all constituent material ingredients of PLA. A large number of studies reported in recent years have examined the use of secondary materials, such as recycled plastic aggregates as a partial replacement for coarse aggregates in lightweight concrete applications. However, the validity of this argument is yet to be supported by conducting further studies on the potential of the recycling of concrete containing recycled waste plastic after its service life. The above-mentioned further research streams would both contribute towards assessing the feasibility and effectivity of a circular economy framework for the reuse and recycling of plastic waste materials and its reprocessing into construction applications.

It is also essential to mention that this study promotes the use of recycled plastics in construction in general, with a special focus on LLDPE-based aggregates as partial or full replacement to natural aggregates. The cases described in this research utilize the thought of using the LLDPE-based concrete as either a replacement for lightweight concrete (in non-structural elements) or as a replacement to structural concrete for short structures (3 stories or less and with slab spans of $6 \mathrm{~m}$ or less). According to the International Building Code (IBC), the minimum acceptable strength for structural concrete is 2500 psi (around $17 \mathrm{MPa}$ ). The studied LLDPE-based concrete has a strength of $18 \mathrm{MPa}$, which passes this threshold. For additional safety, we only considered having this material in slabs, while keeping the columns and foundations at $25 \mathrm{MPa}$ (traditional concrete). Even with this, it should be clearly noted that further studies and structural tests are required to validate and give more confidence in the use of LLDPE-based concrete as a structural concrete.

\section{Conclusions}

This paper examines the potential benefits green processed lightweight aggregates (PLA) can provide to a project seeking LEED certification in accordance with the requirements of LEED v4 for Building Design and Construction. The sustainability attributes of PLA contribute to the sustainable development of the construction and infrastructure industry and address several sustainable development goals (SDGs). LEED points are not earned for the use of a particular sustainable building material or product, but the use of PLA as a total replacement for coarse aggregates in lightweight concrete applications would contribute to earning points towards LEED certification, mainly in the "Materials and Resources (MR)" category, but also in the "Innovation (ID)" category. The main conclusions of this study are detailed below.

- $\quad$ MR Credit 1: Building Life Cycle Impact Reduction, 1-4 points are attainable based on the decreased unit weight of PLA compared to conventional light weight aggregates (LWA, and the reduced overall weight of the final building structure.

- MR Credit 2.2: Building Product Disclosure and Optimization-Sourcing of Raw Materials, 1-2 points are possible given that the constituent polymers and fillers used to produce PLA are readily available, in addition to the reduced demand for natural aggregates in the construction sector resulting from the use of PLA.

- $\quad$ MR Credit 2.3: Building Product Disclosure and Optimization-Material Ingredients 1 point is achievable as a result of the mitigation of landfill concerns and global carbon emissions resulting from the sustainable use of plastic wastes as alternative construction materials, in addition to the mitigation of environmental and economic problems associated with sandstorms in specific countries resulting from the use of red dune sand as a filler.

- ID Credit: Pilot 1 point can be realized by one of two options; either the demonstration of the low values of thermal conductivity of PLA for dry conditions or the low percentage of water absorption for LLDPE plastic.

The integration of sustainable building materials from waste streams is the future challenge, yet prospect of the construction industry. The thoughtful selection of PLA is one of many possible research directions geared towards the innovation in construction materials, an aspect which is necessitated by the substantial amount of harmful emissions and resource-intensive nature of the construction industry. As such, the replacement of 
conventional lightweight aggregates in concrete with recycled plastic made from linear low-density polyethylene (LLDPE) is a significant contributor to the sustainable development of both the construction and plastic-recycling industries. PLA meets the requirements for sustainability through its realization of energy saving and cost reduction, water conservation, safeguarding of natural resources and the environment, while supporting the local economy. The guidelines provided by the research will enable developers to attain higher LEED scores, thus, maximizing the financial and environmental benefits of their buildings.

Author Contributions: Conceptualization, F.K.A. and I.S.A.; Methodology F.K.A., I.S.A., S.H.; Resources, F.K.A., S.H.; data curation, S.H.; writing-original draft preparation, S.H.; review and editing, F.K.A.; I.S.A.; supervision and administration, F.K.A. All authors have read and agreed to the published version of the manuscript.

Funding: The authors extend their appreciation to the Research Supporting Project number (RSP2020/264), King Saud University, Riyadh, Saudi Arabia for funding this work.

Conflicts of Interest: The authors declare no conflict of interest.

\section{References}

1. UN Environment and International Energy Agency. Towards a Zero-Emission, Efficient, and Resilient Buildings and Construction Sector, Global Status Report. 2017. Available online: https://www.worldgbc.org/sites/default/files/UNEP\%20188_GABC_en\% 20(web).pdf (accessed on 29 January 2019).

2. Durdyev, S.; Zavadskas, E.K.; Thurnell, D.; Banaitis, A.; Ihtiyar, A. Sustainable construction industry in Cambodia: Awareness, drivers and barriers. Sustainability 2018, 10, 392. [CrossRef]

3. Gettu, R.; Pillai, R.G.; Santhanam, M.; Basavaraj, A.S.; Rathnarajan, S.; Dhanya, B.S. Sustainability-based decision support framework for choosing concrete mixture proportions. Mater. Struct. 2018, 51, 165-181. [CrossRef]

4. Metha, K. Advancements in Concrete Technology. Concr. Int. 1999, 21, 69-76.

5. Thongkamsuk, P.; Tondee, T.; Sudasna, K. Waste generated in high-rise buildings construction: A current situation in Thailand. Energy Procedia 2017, 138, 411-416. [CrossRef]

6. Tapali, J.G.; Demis, S.; Papadakis, V.G. Sustainable Concrete Mix Fesign for a Target Strength and Service Life. Comput. Concr. 2013, 12, 755-774. [CrossRef]

7. Madlool, N.A.; Saidur, R.; Hossain, M.S.; Rahim, N.A. A Critical Review on Energy Use and Savings in the Cement Industries. Renew. Sustain. Energy Rev. 2011, 15, 2042-2060. [CrossRef]

8. Karim, Y.; Khan, Z.; Alsoufi, M.S.; Yunus, M. A Review on Recycled Aggregates for the Construction Industry. Am. J. Civ. Eng. Arch. 2016, 4, 27-33.

9. Loon, L.Y.; Abd Karim, A.T.; Abdul Rahman, I.; Boon, K.H.; Hani, S.; Nagapan, S.; Reza, F.V. Alternative Aggregates for Sustainable Construction. Int. J. Zero Waste Gener. 2013, 1, 1-6.

10. Attanasio, A.; Largo, A.; Alvarez, I.L.; Sonzogni, F.; Balaceanu, L. Sustainable Aggregates from Secondary Materials for Innovative Lightweight Concrete Products. Heron J. 2015, 60, 5-26.

11. Pizoń, J.; Gołaszewski, J.; Alwaeli, M.; Szwan, P. Properties of Concrete with Recycled Concrete Aggregate Containing Metallurgical Sludge Waste. Materials 2020, 13, 1448. [CrossRef]

12. Awoyera, P.O.; Adesina, A. Plastic Wastes to Construction Products: Status, Limitations and Future Perspective. Case Stud. Constr. Mater. 2020, 12, 1-11. [CrossRef]

13. Freedonia. Global Construction Aggregates-Demand and Sales Forecasts, Market Share, Market Size, Market Leaders. 2019. Available online: https:/ / www.freedoniagroup.com/World-Construction-Aggregates.html (accessed on 15 November 2019).

14. Zhao, W.; Leeftink, R.B.; Rotter, V.S. Evaluation of the Economic Feasibility for the Recycling of Construction and Demolition Waste in China-The Case of Chongqing. Resour. Conserv. Recycl. 2010, 54, 377-389. [CrossRef]

15. Ghanbari, M.; Abbasi, A.M.; Ravanshadnia, M. Economic and Environmental Evaluation and Optimal Ratio of Natural and Recycled Aggregate Production. Adv. Mater. Sci. Eng. 2017, 2017, 1-10. [CrossRef]

16. Petkovic, G.; Engelsen, C.J.; Håøyad, A.-O.; Breedvelde, G. Environmental Impact from the Use of Recycled Materials in Road Construction: Method for Decision-Making in Norway. Resour. Conserv. Recycl. 2004, 42, 249-264. [CrossRef]

17. Chauhan, S.S. Mining, Development and Environment: A Case Study of Bijolia Mining Area in Rajasthan, India. J. Hum. Ecol. 2010, 31, 65-72. [CrossRef]

18. Peduzzi, P. Sand, Rarer than one Thinks. Environ. Dev. 2014, 11, 208-218.

19. Evangelista, L.; Guedes, M.; de Brito, J.; Ferro, A.C.; Pereira, M.F. Physical, Chemical and Mineralogical Properties of Fine Recycled Aggregates Made from Concrete Waste. Constr. Build. Mater. 2015, 86, 178-188. [CrossRef]

20. Paldyna, J.; Krasnodebska-Ostrega, B.; Kregielewska, K. The Assessment of Environmental Pollution Caused by Mining and Metallurgy Wastes from Highly Polluted Post-Industrial Regions in Southern Poland. Environ. Earth Sci. 2013, 68, 439-450. [CrossRef] 
21. Udom, I.J. Impact of Floodplain Aggregate Extraction in Water Quality in Akwa Ibom State, Nigeria. Umudike J. Eng. Technol. 2018, 4, 168-177.

22. Yerramala, A. Properties of Concrete with Eggshell Powder as Cement Replacement. Indian Concr. J. 2014, 88, 94-105.

23. Daniyal, M.; Ahmad, S. Application of Waste Ceramic Tile Aggregates in Concrete. Int. J. Innov. Res. Sci. Eng. Technol. 2015, 4, $12808-12815$.

24. Olukanni, D.O.; Ede, A.N.; Ndambuki, J.M.; Olofinnade, O.M. Effect of Substitution of Crushed Waste Glass as Partial Replacement for Natural Fine and Coarse Aggregate in Concrete. Mater. Sci. Forum 2016, 866, 58-62.

25. Zheng, C.; Lou, C.; Du, G.; Li, X.; Liu, Z.; Li, L. Mechanical Properties of Recycled Concrete with Demolished Waste Concrete Aggregate and Clay Brick Aggregate. Results Phys. 2018, 9, 1317-1322. [CrossRef]

26. Alqahtani, F.K.; Khan, M.I.; Ghataora, G. Synthetic Aggregate for Use in Concrete. U.S. Patent US 8,921,463 B1, 30 December 2014.

27. Sani, M.S.; Ismail, M.I.; Rahman, M.A.; Muftah, F. Waste Paper Ash Pellets as Coarse Aggregate Replacement in Concrete. Int. J. Eng. Adv. Technol. 2019, 8, 112-117.

28. Alqahtani, F.K.; Zafar, I. Characterization of Processed Lightweight Aggregate and Its Effect on Physical Properties of Concrete. Constr. Build. Mater. 2020, 230, 116992. [CrossRef]

29. Alqahtani, F.K.; Ghataora, G.; Khan, M.I.; Dirar, S. Novel lightweight concrete containing manufactured plastic aggregate. Constr. Build. Mater. 2017, 148, 386-397. [CrossRef]

30. Alqahtani, F.K.; Khan, M.I.; Ghataora, G.; Dirar, S. Production of Recycled Plastic Aggregates and Its Utilization in Concrete. J. Mater. Civ. Eng. 2018, 29, 04016248. [CrossRef]

31. Sule, J.; Emmanuel, S.; Joseph, I.; Ibhadobe, O.; Alfred, B.Y.; Waziri, F.I.; Sunny, E. Use of Waste Plastics in Cement-Based Composite for Lightweight Concrete Production. Int. J. Res. Eng. Technol. 2017, 2, 44-54.

32. Babafemi, A.J.; Šavija, B.; Paul, S.C.; Anggraini, V. Engineering Properties of Concrete with Waste Recycled Plastic: A Review. Sustainaibility 2018, 10, 3875. [CrossRef]

33. Goubran, S. On the Role of Construction in Achieving the SDGs. J. Sustain. Res. 2019, 1, 1-52.

34. Lynch, A.J.; Mosbah, S.M. Improving Local Measures of Sustainability: A Study of Built-Environment Indicators in the United States. Cities 2017, 60, 301-313. [CrossRef]

35. Di Foggia, G. Energy Efficiency Measures in Buildings for Achieving Sustainable Development Goals. Heliyon 2018, 4, e00953. [CrossRef] [PubMed]

36. Czerwinska, D. World Green Building Council. 2017. Available online: https://www.worldgbc.org/green-building-sustainabledevelopment-goals (accessed on 4 December 2020).

37. Booz Allen Hamilton. Green Building Economic Impact Study. Available online: http://go.usgbc.org/2015-Green-BuildingEconomic-Impact-Study.html (accessed on 4 December 2020).

38. El-Adaway, I.H.; Truax, D.D. Managing the LEED Analysis for the New Civil and Environmental Engineering Complex at Mississippi State University. J. Manag. Eng. 2014, 30, 05014002. [CrossRef]

39. USGBC Checklist: LEED v4 for Building Design and Construction. 2016. Available online: https://www.usgbc.org/resources/ leed-v4-building-design-and-construction-checklist (accessed on 10 December 2020).

40. Zheng, D.Y. Does LEED Save Energy? A Case Study of LEED at UC Berkeley. 2013. Available online: https:/ / nature.berkeley. edu/classes/es196/projects/2013final/ZhengD_2013.pdf (accessed on 5 November 2020).

41. Ribero, Ó.; Garzón, D.; Alvarado, Y.; Gasch, I. Economic Benefits of LEED Certification: A Case Study of the Centro Ático Building. Rev. Ing. Constr. 2016, 31, 139-146. [CrossRef]

42. Eichholtz, P.; Kok, N.; John, Q.M. Doing Well by Doing Good? Green Office Buildings. Am. Econ. Rev. 2010, 100, 2492-2509. [CrossRef]

43. Reddy, V.S. Sustainable Construction: Analysis of Its Costs and Financial Benefits. Int. J. Innov. Res. Eng. Manag. 2016, 3, 522-525. [CrossRef]

44. Willar, D.; Waney, E.V.; Pangemanan, D.D.; Mait, R.E. Sustainable Construction Practices in the Execution of Infrastructure Projects-The extent of implementation. Smart Sustain. Built Environ. 2019, 1-19. [CrossRef]

45. Liu, Z.-J.; Pypłacz, P.; Ermakova, M.; Konev, P. Sustainable Construction as a Competitive Advantage. Sustainability 2020, $12,5946$. [CrossRef]

46. Aghimien, D.O.; Aigbavboa, C.O.; Thwala, W.D. Microscoping the Challenges of Sustainable Construction in Developing Countries. J. Eng. Des. Technol. 2019, 17, 1110-1128. [CrossRef]

47. Oke, A.E.; Aigbavboa, C.O.; Semenya, K. Energy Savings and Sustainable Construction: Examining the Advantages of Nanotechnology. Energy Procedia 2017, 142, 3839-3843. [CrossRef]

48. USGBC. LEED v4.1: Building Design and Construction; USGBC: Washington, WA, USA, 2020.

49. AEA Group. Plastic Waste in the Environment: Revised Final Report; IEEP: Paris, France, 2011.

50. Al-Salem, S.M.; Al-Nasser, A.; Al-Dhaffer, A.T. Multi-variable Regression Analysis for the Solid Waste Generation in the State of Kuwait. Process Saf. Environ. Prot. 2018, 119, 172-180. [CrossRef]

51. Sofi, A. Sustainable Concrete with Waste Tyre Rubber-An Overview. J. Chem. Pharm. Sci. 2016, 9, 848-853.

52. Tang, Z.; Zhang, L.; Huang, Q.; Yang, Y.; Nie, Z.; Cheng, J.; Chai, M. Contamination and Risk of Heavy Metals in Soils and Sediments from a Typical Plastic Waste Recycling Area in North China. Ecotoxicol. Environ. Saf. 2015, 122, 343-351. [CrossRef] [PubMed] 
53. Shi, X.; Xu, G. Characteristics and Applications of Fly Ash as a Sustainable Construction Material: A State-of-the-Art Review. Resour. Conserv. Recycl. 2018, 136, 95-109.

54. Sahu, B.K.; Jayaram, S. Environmental Impacts of Fly Ash. Botsw. J. Technol. 2000, 9, 9-13.

55. Vairagade, V.S.; Parbat, D.K.; Dhale, S.A. Fly Ash as Sustainable Material for Green Concrete-A State of Art. Int. J. Res. Eng. Sci. Technol. 2015, 1, 17-24.

56. Król, A. The Role of the Silica Fly Ash in Sustainable Waste Management. E3S Web Conf. 2016, 10, 00049. [CrossRef]

57. Ash Development Association of Australia. Fly Ash Technical Note No. 11: Use of Fly Ash to Achieve Enhanced Sustainability in Construction; ADAA: Wollongong, Australia, 2012.

58. Sonbul, A.R.; Abu Seif, E.-S.S. Geotechnical Performance of Sandy Bricks Made with Fine Aggregates of Sand Dunes, Saudi Arabia. Arab. J. Geosci. 2019, 12, 1-14.

59. Adajar, M.Q.; de Guzman, E.; Ho, R., Jr.; Palma, C., III; Sindico, D. Utilization of Aggregate Quarry Waste in Construction Industry. Int. J. Geomate 2017, 12, 16-22. [CrossRef]

60. Blanco, F.; García, P.; Mateos, P.; Ayala, J. Characteristics and properties of lightweight concrete manufactured with cenospheres. Cem. Concr. Res. 2000, 30, 1715-1722. [CrossRef] 